Western University

Scholarship@Western

Law Publications

Law School

2014

Constructive Ambiguity and the Meaning of "Gender" for the International Criminal Court

Valerie Oosterveld

Follow this and additional works at: https://ir.lib.uwo.ca/lawpub

Part of the Law Commons

Citation of this paper:

Oosterveld, Valerie, "Constructive Ambiguity and the Meaning of "Gender" for the International Criminal Court" (2014). Law

Publications. 96.

https://ir.lib.uwo.ca/lawpub/96 


\title{
Constructive Ambiguity and the Meaning of "Gender" for the International Criminal Court
}

\author{
VALERIE OOSTERVELD \\ University of Western Ontario Faculty of Law, Canada
}

\begin{abstract}
The 1998 negotiations surrounding the inclusion of the term "gender" in the International Criminal Court's (ICC) Rome Statute were polarized, resolved only by resorting to constructive ambiguity: indefinite language used to resolve disparate points of view. Resorting to constructive ambiguity in defıning the term permitted its retention in the Statute - widely viewed as a positive outcome - but it also led to continuing dissention about the actual meaning of that definition. A number of feminist commentators have critiqued the definition as narrow without deeply or strategically engaging with it, and conservative commentators have used these critiques as "evidence" that the definition must be narrow. The ICC itself has largely refrained from interpreting the term, with the exception of the Prosecutor in a 2014 draft policy document, while the Holy See has attempted to impose in other international fora its exclusionary understanding of the ICC's definition. This article begins with an overview of the Rome Statute discussions on "gender." It then analyzes responses to this definition since 1998, illustrating that the use of constructive ambiguity has led to continuing contestation rather than certainty. It concludes by considering the usefulness of resorting to constructive ambiguity to define highly-contested terms.
\end{abstract}

International Criminal Court, gender, constructive ambiguity

Keywords

The 1998 negotiations surrounding the inclusion of the term "gender" in the International Criminal Court's (ICC) Rome Statute (1998) served as a flashpoint of polarized debate among states, feminist nongovernmental actors and conservative nongovernmental representatives. The dispute around "gender" lasted until very late in the Statute's drafting process, and was only resolved 
through resorting to constructive ambiguity, a tactic used by diplomats and other negotiators, especially in consensus negotiations, to adopt indefinite language to seemingly resolve disparate points of view. The definition of "gender" ultimately included in article 7(3) of the Rome Statute is therefore intentionally opaque: "For the purpose of this Statute, it is understood that the term 'gender' refers to the two sexes, male and female, within the context of society. The term 'gender' does not indicate any meaning different from the above" (Rome Statute of the International Criminal Court 1998). Resorting to constructive ambiguity in defining the term permitted its retention in the Statute - widely viewed as a positive outcome - but it also led to continuing dissention about the actual meaning of that definition. This confusion has had spillover effects in the intervening sixteen years. For example, the ICC itself has largely refrained from engaging with the "gender" definition in its Statute (with the recent exception of the Office of the Prosecutor in a draft policy document), while the Holy See attempts to impose its particular understanding of the ICC's definition as grounded in biological, sexual differences between males and females within other international fora, despite the definition's limited applicability to "the purposes of this Statute."

This article begins with an overview of the Rome Statute discussions on the term "gender." It then analyzes responses to this definition since 1998 by feminists, conservatives, the ICC and others, illustrating that the constructive ambiguity used in the definition has led to continuing contestation rather than certainty. It concludes by considering the usefulness of resorting to constructive ambiguity when defining highly-contested terms.

\section{THE ROME STATUTE "GENDER" NEGOTIATIONS}

The International Law Commission's 1994 Draft Statute for an ICC (International Law Commission 1994) was the initial discussion document around which the subsequent ICC negotiations were structured, and it did not use the term "gender." Thus, any gender-sensitive language eventually added to the Statute had to be proposed and supported, and was therefore subject to compromise. The ICC negotiations between 1996 and early 1998 led to everincreasing references to the term "gender" throughout a number of draft provisions. This was in a large part due to the cooperation between a number of gender-supportive states and the newly-formed coalition of nongovernmental organizations (NGOs) known as the Women's Caucus for Gender Justice in the International Criminal Court. As a result, "gender" was added to the list of persecutory grounds within the crimes against humanity provision, alongside persecution directed against individuals based on political, racial, national, ethnic, cultural or religious grounds (Preparatory Committee on the Establishment of the ICC 1997a, 4-5). Also, draft articles outlining prosecutorial responsibilities indicated that the Prosecutor must, when investigating and prosecuting crimes, consider the gender of victims and witnesses and take 
into account whether they suffered from crimes involving "sexual or gender violence" (Preparatory Committee on the Establishment of the ICC 1997b, 16, 36). Similarly, the Court was tasked in a draft provision with ensuring the "safety, physical and psychological well-being, dignity and privacy of victims and witnesses... including ... victims and witnesses of sexual and gender violence" (Preparatory Committee on the Establishment of the ICC 1997b, 36). In addition, states considered the governing general principles of law for the ICC, adopting draft article 20(3):

\begin{abstract}
The application and interpretation of law pursuant to this article must be consistent with internationally recognized human rights, which include the prohibition on any adverse distinction founded on gender, age, race, colour, language, religion or belief, political or other opinion, national, ethnic or social origin, wealth, birth or other status, or any other similar criteria. (Preparatory Committee on the Establishment of an International Criminal Court 1998)
\end{abstract}

The success of certain states and the Women's Caucus in gaining references to the term "gender" prompted the rise of conservative state and NGO opposition. By the final set of negotiations at the 1998 Diplomatic Conference, this opposition largely coalesced around the positions of the Holy See and a coalition of vocal conservative Arab states, as well as a small set of conservative North American NGOs (Glasius 2006, 83; David M. Kennedy Center for International Studies 1998). These counter-activists placed the Women's Caucus and the gender-supportive states in a defensive position (Bedont and Hall-Martinez 1999, 67). This was because they did not necessarily wish to ensure that the ICC's Statute reflected their own views, but rather wished to oppose provisions they viewed as "anti-family" (Glasius 2006, 82).

The numerous references to "gender" added to the draft Statute between 1996 and early 1998, the strength of the Women's Caucus and state supporters and the existence of organized opposition among conservative civil society representatives and states meant that the 15 June-17 July 1998 Rome Diplomatic Conference became a battleground on the meaning of "gender." Conservative NGOs distributed lobby papers targeting the term "gender" as being "vague" and problematic, potentially undermining "traditional moral, cultural, and religious values," and arguing that the term could be used to establish or advance "rights" based on sexual conduct or sexual orientation (David M. Kennedy Center for International Studies 1998; REAL Women of Canada 1998). This was in line with the Holy See's previously-stated position (United Nations 1996, 162) and with the views expressed by certain other conservative states. For example, when some states indicated support for the inclusion of gender as a prohibited ground of persecution (UN Diplomatic Conference 1998a, para. 163 (Italy), para. 169 (Ireland); UN Diplomatic Conference 1998b, para. 26 (Israel)), the state delegate from Azerbaijan articulated the core of opposition concerns when he asked: "Did that provision imply that a 
conviction by a national court for homosexual acts might be regarded as persecution and thus fall within the jurisdiction of the Court as a crime against humanity?" (UN Diplomatic Conference 1998c, para. 61).

The issue was confronted directly in negotiations on applicable law. The draft article concluded with a clause indicating that the ICC's application and interpretation of law must be consistent with internationally-recognized human rights, which include the prohibition of adverse distinction founded on gender and other grounds. Several countries argued that the term "gender" or, alternatively, all of the listed grounds, should be deleted (Steains 1999, 372). This set the stage for a contentious debate near the end of the Diplomatic Conference on 11 and 13 July 1998. Almost every state representative speaking in those meetings indicated support for, or opposition to, retaining the term "gender." There were two main arguments made in favor of using the term. The first was that the term "gender" has been commonly used for over a decade in resolutions of the UN General Assembly and Commission on Human Rights, ${ }^{1}$ as well as other documents within the UN system, such as the Beijing Declaration and Platform for Action (United Nations 1996, 1132). ${ }^{2}$ The second argument was that "gender" is the more accurate term; while "sex" refers only to biological distinctions, "gender" captures social differences (Oosterveld 1998, e.g. Canada on $11 \mathrm{July}^{3}$ ).

There were two main arguments made against the use of "gender." First, those opposed feared that the term provides rights based on sexual orientation (Oosterveld 1998, Qatar on 11 July and Yemen on 13 July; Steains 1999, 372), creates rights for a "third sex" (Oosterveld 1998) ${ }^{4}$ or imposes other cultures which permit "sexual orientation and deviation" on states (Oosterveld 1998, Bahrain on 13 July). They indicated that their religious beliefs did not permit rights based on sexual orientation (Oosterveld 1998, Qatar and Syria on 13 July). The second argument was that the meaning of "gender" is too vague, consequently making the term hard to translate and violating the principle of legality (Oosterveld 1998, Egypt, Guatemala, Saudi Arabia and Yemen on 13 July).

Those supportive of the use of the term "gender" proposed using the same (constructively ambiguous) solution used in the 1995 UN Fourth World Conference on Women in Beijing, but this was rejected by the opposing side (Oosterveld 1998, proposed by the Chair of the Working Group and Canada on 11 July, and supported on 13 July by Australia, Belgium, Chile, Colombia, Costa Rica, Finland, Italy, Mozambique, Norway, Senegal and the United States). ${ }^{5}$ Apart from deletion, those opposed to "gender" proposed replacing it with "man, woman and child," "the two sexes, male and female," "sex," "male and female" or "men and women" (Oosterveld 1998, Qatar on 11 and 13 July, and Venezuela, Brunei and Guatemala on 13 July). None of these proposals gained traction as an overarching solution, which had to be consensual, as states had agreed that voting would only occur as a last resort (Kirsch 1999, 453). In addition, states opposed to the term did not want it go to a vote, because their numbers were smaller. ${ }^{6}$ At the same time, the counter-activists 
wished to dominate the agenda for as long as possible so as to gain timerelated leverage and to retain the advantage open to vocal opponents within international consensus negotiations. ${ }^{7}$

By the end of the 13 July negotiations, it became clear that the most likely solution was to adopt a specific definition that was acceptable to both sides. The Chair of the Working Group on Applicable Law therefore delegated the responsibility of finding a joint solution to the representatives of Canada, Chile, Qatar and Saudi Arabia. For the supportive states (represented by Canada and Chile), it was important to reflect the social construction of identities in societies, including different sexualities. Thus, these states proposed wording such as "men and women and their roles in society," "being a male or female and its [associated] implications in society," "men and women and their functions in society," "males and females within society," "males and females and their societal relationships," and "males and females in the context of society" (Steains 1999, 374, n. 52; Oosterveld 2005, 64). In contrast, the opposing states wanted "gender" to be tethered as closely as possible to biological sex because they felt this would help to instantiate heteronormativity. Thus, they proposed using "the two sexes" (Oosterveld 2005, 64). Both sides combined their ideas, trying to select words that would still reflect their views, resulting in a draft text reading: "For the purposes of this Statute, it is understood that the term 'gender' refers to the two sexes, male and female, [and their roles] within society [in the context of society]" (Oosterveld 2005, 64). The opposing states agreed to a reference to "society," provided that it be adapted to "their society" or have "and the traditional family unit" added afterward, and that it end with the sentence: "The term does not imply the existence of more than two sexes" (Oosterveld 2005, 64). Both requests were countered by the supportive states, which did not accept any restrictive additions to the "society" reference, and suggested instead an ending phrase from the Beijing solution: "The term does not imply any new meaning or connotation of the term different from accepted prior usage" (Steains 1999, 374, n. 52; Oosterveld $2005,65)$. After further negotiation, the first phrase was accepted and included in the Statute as: "For the purposes of this Statute, it is understood that the term 'gender' refers to the two sexes, male and female, within the context of society." Under intense time pressures, the final phrase morphed into "The term 'gender' does not indicate any meaning different from accepted prior usage" (supported by the pro-gender states), and finally, "The term 'gender' does not indicate any meaning different from the above" (supported by the anti-gender states) (Oosterveld 2005, 65).

The final definition is a study in constructive ambiguity. The reference to "the two sexes, male and female" and the final sentence's reference back to these words satisfied the opposing states. The reference to "within the context of society" satisfied the supportive states. Since the final sentence was tautological, the pro-gender states felt that it did not restrict the sociological reference. Both sides felt that the definition had "sufficient flexibility as well as precision," even though it was also seen as "unusual" (Steains 1999, 
374). Ultimately, the definition was listed in article 7(3), on crimes against humanity, as this was the first place it occurred in the Statute. All subsequent references in the Statute included the phrase "as defined in article 7(3)."

The definition was greeted by the Women's Caucus with some frustration, as well as relief that the term was retained in the ICC's Statute. For example, the Caucus' Rhonda Copelon stated: "The definition of gender is going to look odd. It's outrageous that we had to fight a ridiculous five-week battle to hold onto something that was widely acknowledged by the UN system" (Dickens 1998). Alda Facio, also a leading member of the Caucus, wrote that the "gender" definition "is unfortunate, [but] having the term in a legal or 'hard' international document as opposed to a policy or 'soft' document... is a gain for real justice" (Glasius 2006, 92).

Right-wing NGOs hailed the definition as a complete or qualified success. Family Voice concluded that "gender" was successfully defined as "male" and "female," and that "advocates can no longer assert" that "gender" is a social construct unrelated to biological sex (Wilkins, Perry, and Mumford $1998,1,7)$. However, conservative NGOs also expressed worry that their campaign to rid the Statute of the potential to protect rights based on sexual orientation or gender identity had not been entirely successful: "Pro-family activists believe this definition largely eliminates any hazards" of permitting a "prohomosexual interpretation," but the "context of society" phrase may be a "loophole" (Evans 1998; LifeSite 1998; McFeely 1998, 17) or "could be used by western legislative activist judges to undermine the traditional values intent of the entire definition of 'gender'" (LifeSite 1998). More pointedly, representatives of Family Voice indicate that the definition is "not perfect" because the phrase "context of society" "does provide room to argue that 'gender' is not limited exclusively to biology" (Wilkins, Perry, and Mumford 1998, 7, n. 25).

With both sides simultaneously happy and unhappy, the definition certainly fulfilled the diplomatic terms for constructive ambiguity: each side gained vague language that can simultaneously mean different things to different people. They also both lost some certainty, in that the actual interpretation was left to the Prosecutor and, ultimately, the judges of the ICC. ${ }^{8}$ Each side hoped that the words chosen would lead future Court officials to construe the term to match their views.

\section{POST-1998 RESPONSES TO THE "GENDER" DEFINITION}

While constructive ambiguity can create normative flexibility by preserving multiple possible meanings of a term at a given moment in time, it also risks creating uncertainty and discordance until a binding interpretation is adopted. Uncertainty and discordance have been a hallmark of commentary on the Rome Statute's definition of "gender" over the past sixteen years. 
Since the adoption of article 7(3) in the Rome Statute, the feminist literature has largely been critical of the definition: for example, describing it as a "failure" or as "limited" (Moshan 1998, 178; Chinkin and Freeman 2012, 15). Within the critiques, there have been two strands of concern. The first focuses on the manner in which the definition links biological sex with the social construction of gender. For these commentators, the definition causes disquiet because it reflects "second wave" feminist thinking, which situated sex as a matter of biology and gender as the socially-constructed meaning of sex (Charlesworth 2005, 14). It thus did not reflect newer feminist thinking extant in 1998 (stemming from, e.g., Butler 1990), which posited both sex and gender as socially constructed, with the result that gender need no longer be defined in relation to sex (Butler 1990, 87).

Most of the feminist commentators raising this concern seem to interpret the definition extremely narrowly, reading it as "present[ing] gender as primarily an issue of biology rather than one of social construction" (Charlesworth and Chinkin 2000, 335). Indeed, some feel that the definition eliminates the social construction of gender entirely, although they do not explain what "within the context of society" means. For example, Hilary Charlesworth $(1999,394)$ has argued that the definition "wrongfully elides" "gender" and "sex," making the former mean the same as the latter, thereby not acknowledging that "gender is a constructed and contingent set of assumptions about female and male roles" (see also Coomaraswamy 2001, para. 19). Conservative commentators use these feminist interpretations as "evidence" that the definition is limited and focused on biology (Adolphe 2012, 22-25, 27).

The second strand of feminist critique of the "gender" definition construes the definition as excluding the possibility that sexuality can be considered through the phrase "within the context of society." For example, Stephanie Farrior $(2003$, 589) states that the Rome Statute's definition is "limiting" because it "ensure[s] that persecution on the basis of sexual orientation would not be covered." Christine Chinkin $(2009,77)$ classifies "this controversial definition" as having "the effect of excluding issues of sexuality" (see also Cossman 2002, 283-284). On the other hand, Catharine MacKinnon (2013, 110) circumspectly observes that the Rome Statute's definition “does not explicitly encompass gays and lesbians as such, but they are of course covered as women and men, and crimes of discrimination against them as gay or lesbian are often - in my view virtually always - gendered."

Some of this feminist analysis is based upon an influential book chapter written by Cate Steains, a state representative from Australia deeply involved in the ICC negotiations. That chapter states that the second sentence of the definition ("The term 'gender' does not indicate any meaning different from the above") was "ultimately included to forestall any implication that the issue of sexual orientation could be raised in connection with Article 7(3)" (Steains 1999, 374). Given this statement by a central player in the gender-related negotiations, it is understandable that various feminist commentators would conclude that the conservative states had "won" in this regard. However, Steains 
indicated to this author, in an email dated 22 January 2004, that this crucial sentence was not in her original chapter, stating that this "was language inserted by the editor without consulting [her]" and that she would have, if given the chance, "repudiated this sentence in the strongest of terms as being a deeply biased view of the debate and factually incorrect." According to Steains, her original submission to the editor had read: "The second sentence was included upon the insistence of the 'anti-gender' delegations, despite arguments by the 'pro-gender' delegations that it was superfluous." She goes on to indicate the role of constructive ambiguity: "The indisputable fact of the matter is that during the negotiations in Rome there was no consensus as to whether or not the definition of gender should include sexual orientation" (emphasis in original). Had Steains' original sentence been published as submitted, perhaps this second strand of feminist critique might have been muted. ${ }^{9}$

Janet Halley $(2009,106)$ describes the feminist response to the Rome Statute's definition of "gender" as having been "lavishly assailed by feminists, always on the ground that it gave up too much criminalization." Halley is correct that the concerns, as outlined above, were, and still are, about what the definition seems to have lost. The feminist critics would have preferred a different type of definition, although they do not indicate the wording they would have preferred to see. Halley's view is that the Women's Caucus aimed too high (and too wide) in the first place, and that therefore the feminist critique should focus on the initial goals of the Caucus rather than on an evaluation of the end result.

Not all of the feminist evaluation of the definition has been negative; although, admittedly, no feminist commentator lauds the definition's language. Not surprisingly, those who were involved in, or supportive of, the Women's Caucus for Gender Justice during the ICC negotiations do not agree with the negative conclusions of the feminist theorists outlined above. For example, the late Rhonda Copelon $(2000,237)$, a central senior figure in the Caucus, admitted that the wording of the "gender" definition is "peculiar and circular," but argues that feminist critics are wrong. First, she countered that the phrase "within the context of society" "was explicitly intended to incorporate the sociological or social construction of gender" (Copelon 2000, 237). Second, to the argument that the conservative states had somehow "won" the exclusion of sexual orientation or gender identity from the definition, she adds:

The words do not support such an exclusion: even the accepted definition of 'gender' necessarily embraces discrimination based on a decision not to behave according to a prescribed gender role, whether it be in the realm of housekeeping, work, or sexuality. (Copelon 2000, 237)

She also argues that "it is highly dubious to argue that any ambiguity should be resolved in favour of discrimination, especially in a statute establishing the highest international institution of universal justice" (Copelon 2000, 237; see 
also Bedont 1999, 187; Bedont and Hall-Martinez 1999, 68). Pam Spees (2003, 1244) focuses on the critics who claim that the definition excludes sexual orientation by arguing that "[p]ersecution on the basis of sexual orientation or differing gender identities could be viewed as targeting a group or collectivity by virtue of its nonadherence to norms or expectations of gender roles in a given social context" and therefore understood within the phrase "within the context of society." This author also adopts a more optimistic viewpoint, pointing out that the negative conclusions of the feminist commentators above are not supported by the negotiation history or the actual (rather than imputed) wording of the "gender" definition (Oosterveld 2005, 72-84).

There is also affirmative commentary from those not connected with the Women's Caucus. For example, the Special Rapporteur on Contemporary Forms of Slavery found that the definition was "consistent with other, more clearly stated formulations" adopted within the UN that include reference to socially-constructed norms (McDougall 2000, para. 26). This same view has been expressed by Navanethem Pillay, the current UN High Commissioner on Human Rights (Pillay 2008, 20).

The generalist international criminal law literature rarely focuses on the "gender" definition but, where it does, the result shows that there is no consensus of understanding. Machteld Boot and the late Christopher Hall $(2008,273)$, in their analysis of article 7(3), interpret the phrase "context of society" to incorporate a sociological or social construction of gender. Gerhard Werle (2009, para. 905) reiterates this point. ${ }^{10}$ The members of Sierra Leone's Truth and Reconciliation Commission similarly interpreted the Rome Statute's definition to include the construction of an individual's "particular function in society" (Sierra Leone Truth and Reconciliation Commission 2004, para. 242). That said, William Schabas $(2010,186)$, in his commentary on the Rome Statute, writes: "The ['gender'] paragraph was added at the Rome Conference so as to respond to concerns that the term might appear to endorse homosexuality." However, he cites the Steains chapter statement (Schabas 2010, n.403), which has been repudiated by Steains herself.

Within the conservative academic literature, the main conclusion is that the Rome Statute's definition situates gender within the confines of biological sex and "reject[s] the radical feminist concept of 'gender' as a social construct" (Adolphe 2012, 4). This is illustrated both within the post-Rome Statute conservative advocacy literature and conservative academic analysis. For example, Samantha Singson (2011, 1), writing for the US-based Catholic Family and Human Rights Institute, concludes that gender is a "distinction grounded in biology" and that the Rome Statute definition of the term "gender" does not "add a sociological component of gender to a universally understood biological component" (see also Wilkins, Perry, and Mumford 1998,1 , 7). Jane Adolphe $(2012$, 20) explains that the Holy See - which has been deeply involved in the international discussions around the term "gender" - views gender as "grounded in biological, sexual differences between males and females," and that 
such differences are relevant (e.g., motherhood and fatherhood), but not all roles and relations are fixed in a static pattern (e.g., being born female does not mean that a woman is inferior, cannot drive, be educated, hold a job, etc.). (Adolphe 2012)

According to Adolphe's analysis, the Rome Statute definition takes a similar approach. Adolphe posits that the Holy See's view is supported by states' use of the term "gender" within UN fora as a synonym for "women" and/or "male and female" (Adolphe 2012, 4, 11, 12, 18).

Since the adoption of the Rome Statute in 1998, the Holy See has advocated its interpretation of the Rome Statute definition of "gender" whenever the term arises in international and regional negotiations. For example, while it succeeded in having the definition replicated within the outcome document at the controversial 2001 UN World Conference Against Racism, Racial Discrimination, Xenophobia and Related Intolerance (United Nations 2001, 75, n.1), it has been unsuccessful in doing the same in other fora (e.g. Holy See 2012, para. 5). For example, in the 2011 Council of Europe negotiations on a new Convention on Preventing and Combating Violence Against Women and Domestic Violence, the Holy See attempted to replace the definition of "gender" eventually adopted with the Rome Statute definition (Holy See 2011, 4) ${ }^{11}$ It took a similar position, reiterating the Rome Statute definition as indicative of roles based on innate biological sex, in the 2012 session of the UN Human Rights Council (Holy See 2012, para. 5).

This dichotomous discussion around the ICC's definition of "gender" has largely occurred separate from any consideration of gender within the ICC and its affiliated institution, the Trust Fund for Victims. The ICC itself has not analyzed the meaning of the term in any of its decisions or judgments, though it and the Trust Fund have used the term. Sometimes it appears to be used to mean the same as biological sex, for example when listing the "gender criteria" for the election of judges or reporting on "gender balance" in the recruitment of ICC staff (e.g. ICC Assembly of States Parties 2012). In other situations, however, the term is used to mean socially-constructed norms of maleness and femaleness, such as in the Lubanga case (ICC 2012a, Odio Benito Dissent, paras. 20-2; ICC 2012b, paras. 13, 79). Similarly, other individuals and offices within the Rome Statute system, such as the ICC's Prosecutor, the Office of Public Counsel for Victims and the Trust Fund for Victims, have appeared to be referring to socially-constructed conceptions of maleness and femaleness in their communications. ${ }^{12}$

This approach to social construction is very clear in the June 2014 Policy Paper on Sexual and Gender-Based Crimes issued by the Office of the Prosecutor. This policy paper serves as an internal policy document to "guide the Office in its work relating to sexual and gender-based crimes" (ICC Office of the Prosecutor 2014, para. 7). However, it is also meant to encourage states "to carry out their primary responsibility of investigating and prosecuting crimes, including sexual and gender-based crimes" (ICC Office 
of the Prosecutor 2014, para. 110). In this policy paper, the Office of the Prosecutor understands gender in a nuanced manner, reiterating the article 7(3) definition, followed by: "[t]his definition acknowledges the social construction of gender, and the accompanying roles, behaviours, activities and attributes assigned to women and men, and girls and boys" (ICC Office of the Prosecutor 2014, 3, para. 15). The policy pledges to examine the place of gender in the commission of crimes and their aftermath by considering the "roles of females and males; the different patterns of involvement, behaviour and activities that they have in economic, social and legal systems; the constraints they face relative to each other; and available opportunities" within "complex sets of differing social and cultural expectations" (ICC Office of the Prosecutor 2014, n.17). The Office of the Prosecutor interprets the Statute's references to "gender" in light of internationally-recognized human rights pursuant to article 21(3) on applicable law (ICC Office of the Prosecutor 2014, paras. 26-27). The policy paper consequently refers to "gender norms and inequalities" and "socially constructed gender roles," and also uses both "sex" and "gender" as distinct categories when considering how forms of violence may be predicated on different types, and intersections, of discrimination (ICC Office of the Prosecutor 2014, 3-4 and paras. 16, $20,27)$. It notes that gender-based crimes "are not always manifested as a form of sexual violence" and "may include non-sexual attacks on women and girls, and men and boys, because of their gender, such as persecution on the grounds of gender" (ICC Office of the Prosecutor 2014, para. 16). Finally, the Office considers the linkages between gender, persecution and sexual orientation or gender identity (ICC Office of the Prosecutor 2014, paras. 26-27, n.23, n.25). In other words, the Prosecutor's proposed policy approach is "thick": it considers many facets of gender, potentially resulting in clearer, more fulsome and more nuanced explanations of the content of gender to the judges and other parties.

While this policy paper "does not itself give rise to legal rights" and thus does not bind judicial interpretations of the Rome Statute (ICC Office of the Prosecutor 2014, para. 11), it contains an influential indication that the Office of the Prosecutor currently interprets article 7(3) in the manner hoped for by gender-supportive states in Rome, thus removing - at least at the level of policy - the ambiguity inserted in 1998. This could, in turn, alter judges' consideration of the meaning of the term "gender" and, more broadly, their understanding of the Prosecutor's cases and the ultimate sentences of the perpetrators. Also, as the Rome Statute is premised on the doctrine of complementarity, under which states are provided with the first opportunity to investigate or prosecute serious crimes, states may decide to adopt the Prosecutor's interpretation of the Rome Statute's article 7(3) when carrying out their own cases. All of this will undoubtedly have an impact on whether the Holy See, for example, will continue to hold up article 7(3) as the answer to contested views of the term "gender" within the UN and other fora. 
Constructive ambiguity, applied by diplomats and other negotiators at strategically-important points to gain agreement, ultimately leaves interpretation for another day or to other people (Bell and Cavanaugh 1998-1999, 1356; Kress 2003, 605-606). In the case of the Rome Statute, the intentional vagueness used to define the term "gender" has had long-lasting aftereffects. Feminists agree that the definition uses biological sex as its launching point, but disagree on what comes after that: some argue that the definition excludes the consideration of socially-constructed norms of maleness and femaleness and of sexualities, while others argue that the definition includes both. There is no uniform understanding among generalists of the meaning of the term, while conservative commentators use the lack of agreement among the others to argue that the definition must mean only "male and female" or the naturally-ensuing social roles of biologically male and female individuals. The Holy See presses its view of the definition at every opportunity within the international system. Within the ICC, only the Office of the Prosecutor has directly wrestled with the issue and has only done so recently, ultimately interpreting "gender" in a broad and inclusive manner that refutes the Holy See's approach to the Rome Statute. Other organs of the ICC have not been as clear, using the term at times to mean "biological sex," and at other times to mean something wider.

The use of constructive ambiguity in international negotiations clearly has costs. In this case, the contestation ostensibly solved by the ambiguity has, in fact, continued since 1998, with the Holy See trying to retail the Rome Statute definition as the international legal definition of "gender" and feminist commentators disagreeing among themselves and creating fodder for advocates of the Holy See's position. Feminist international lawyers have largely avoided deep consideration of the ICC's "gender" definition, sometimes engaging in swift and somewhat superficial critiques. These critiques have largely failed to make strategic use of one potential advantage stemming from the elusive wording of the definition: the utilization of constructive ambiguity results in burden shifting, leaving normative clarification to the judges and Prosecutor and taking this role out of the hands of states. This created potential time and space for feminist commentators to elucidate, in a considered rather than reactionary manner, their own understanding of the definition based on current international human rights norms so as to inform the prosecutorial and judicial interpretations. This is what the Holy See has done. If used strategically from the beginning, it is likely that the resulting feminist responses would have been more nuanced, thereby reducing the chances that they would be used by conservative commentators as "evidence" that a narrow reading of article 7(3) must prevail in the Rome Statute and elsewhere.

That said, despite the reflexive and critical feminist response, the Office of the Prosecutor has recently interpreted the definition of "gender" in a comprehensive manner. This illustrates that, from a feminist perspective, constructive ambiguity can be a useful diplomatic tool to define highly contested terms if the ultimate 
interpreter already has a deep understanding of the issue. However, it is not clear that all of the judges have a similar understanding, and therefore there is still danger of a judicially-issued narrow analysis emerging. Thus, strategic and sustained feminist intervention after the adoption of a constructively-ambiguous term is very important, so as to influence the ultimate binding interpretation.

Valerie Oosterveld
University of Western Ontario Faculty of Law
1151 Richmond Street
London, Ontario N6A 3K7, Canada
Email: vooster@uwo.ca

\section{Notes}

1 E.g. Canada cited the specific example of UN Commission on Human Rights 1997, para. 4, and UN General Assembly 1997, paras. 3, 4, 19-21, 25, 27-28, 31-32, 3538, 40-42, 45 and 48. From notes by Oosterveld 1998.

2 At the 13 July 1998 debate, Chile referred to the UN Economic and Social Council 1997 report. See also: Australia, Costa Rica, Greece and United States, Oosterveld 1998.

3 References to countries and dates are to the interventions made by the representatives from those countries on those particular dates.

4 On 11 July, the representative from Qatar indicated that he feared that the term "gender" sanctions male-male and female-female sexual rights and that there are 5-6 kinds of "gender."

5 This interpretive statement was included in the Report of the Fourth World Conference on Women: “(1) the word 'gender' had been commonly used and understood in its ordinary, generally accepted usage in numerous other United Nations forums and conferences; (2) there was no indication that any new meaning or connotation of the term, different from accepted prior usage, was intended in the Platform for Action" (United Nations 1996, 218).

6 The Chair made an oblique reference to this numerical imbalance at the end of the 13 July discussions: Oosterveld 1998, 13 July.

7 See Chappell 2006, 516-517 for a description of how counter-activists use up limited negotiation time as a tactic to limit gains by the transnational women's movement.

8 The term is used in the Rome Statute in: article 7(1)(h) on the crime against humanity of persecution on gender grounds (which will ultimately be interpreted by judges); article 21(3) on the application of law by the Court without adverse distinction founded on gender grounds (ultimately applied by the judges); article 42(9), obligating the Prosecutor to appoint advisers with legal expertise on specific issues, including sexual and gender violence (undertaken by the Prosecutor); article 54(1)(b), obligating the Prosecutor to respect the interests and personal circumstances of victims and witnesses, including their gender, in his/her 
investigations and prosecutions (the duty of the Prosecutor); and article 68(1), obligating the Court to take appropriate measures to protect victims and witnesses, having regard to gender and whether the crime involves sexual or gender violence (involving the Prosecutor, Registrar and the judges).

9 This author has argued that the view that sexual orientation is excluded from the definition of "gender," either explicitly or implicitly, is incorrect: Oosterveld 2005, 77-78.

10 He also comments that persecution on grounds of sexual orientation cannot be included within the persecution definition, but he is referring to the phrase in art. 7(1)(h) "universally recognized as impermissible under international law," not to the art. 7(3) definition of "gender."

11 Article 3(c) of the Convention on Preventing and Combating Violence Against Women and Domestic Violence defines "gender" as "the socially constructed roles, behaviours, activities and attributes that a given society considers appropriate for women and men" (Council of Europe 2011).

12 The Prosecutor has used the term "gender" to indicate a socially constructed norm of maleness or femaleness, e.g. International Criminal Court, Office of the Prosecutor 2012a, 2012b. For examples of other offices using the term, see: International Criminal Court, The Trust Fund for Victims n.d.: "The Gender Perspective"; and International Criminal Court, Office of the Public Counsel for Victims 2012: 25, 33, 68, 100-101, 174, 185 and 295-297, but see 50 and 157 (where it is used to mean "sex").

\section{Notes on contributor}

Valerie Oosterveld is the Associate Dean (Research and Administration) in the Faculty of Law at the University of Western Ontario, where she teaches public international law, the law of international organizations and international criminal law. She has degrees from the universities of Ottawa (BSocSc), Toronto (LLB) and Columbia (LLM and JSD). Her research and writing focuses on gender issues within international criminal justice. Before joining the faculty in 2005, Valerie served in the Legal Affairs Bureau of Canada's then Department of Foreign Affairs and International Trade. In this role, she provided legal advice on international criminal accountability for genocide, crimes against humanity and war crimes. She was a member of the Canadian delegation to the International Criminal Court (ICC) negotiations, as well as the subsequent ICC Assembly of States Parties and the 2010 Review Conference of the Rome Statute of the ICC.

\section{References}

Adolphe, J. 2012. “Gender Wars at the United Nations.” Ave Maria Law Review 11 (1): 1-31. 
Bedont, B. 1999. "Gender Provisions in the Statute of the International Criminal Court." In Vol. 1 of Essays on the Rome Statute of the International Criminal Court, edited by F. Lattanzi, and W. A. Schabas, 183-210. Italy: Il Sierente.

Bedont, B. and K. Hall-Martinez. 1999. "Ending Impunity for Gender Crimes under the International Criminal Court.” The Brown Journal of World Affairs VI (1): 65-85.

Bell, C., and K. Cavanaugh. 1998-1999. “'Constructive Ambiguity' or Internal SelfDetermination? Self-Determination, Group Accommodation, and the Belfast Agreement." Fordham International Law Journal 22: 1345-1371.

Boot, M. as revised by C. K. Hall. 2008. "Paragraph 3: Definition of Gender." In Commentary on the Rome Statute of the International Criminal Court: Observers' Notes, Article by Article, edited by Otto Triffterer, 2nd ed., 273. Oxford, UK: Hart Publishing.

Butler, J. 1990. Gender Trouble: Feminism and the Subversion of Identity. New York: Routledge.

Chappell, L. 2006. “Contesting Women's Rights: Charting the Emergence of a Transnational Conservative Counter-Network." Global Society 20 (4): 491-520.

Charlesworth, H. 1999. "Feminist Methods in International Law." American Journal of International Law 93 (2): 379-394.

Charlesworth, H. 2005. "Not Waving but Drowning: Gender Mainstreaming and Human Rights in the United Nations.” Harvard Human Rights Journal 18 (1): 1- 18.

Charlesworth, H., and C. Chinkin. 2000. The Boundaries of International Law: A Feminist Analysis. New York: Juris Publishing.

Chinkin, C. 2009. "Gender-Related Violence and International Criminal Law and Justice." In The Oxford Companion to International Criminal Justice, edited by A. Cassese, 75-81. New York: Oxford University Press.

Chinkin, C., and M. A. Freeman. 2012. "Introduction." In The UN Convention on the Elimination of All Forms of Discrimination Against Women: A Commentary, edited by M. A. Freeman, C. Chinkin, and B. Rudolf, 2-34. New York: Oxford University Press.

Coomaraswamy, R. 2001. "Report of the Special Rapporteur on Violence Against Women, Ms. Radhika Coomaraswamy, Submitted in Accordance with Commission on Human Rights Resolution 2000/45, Violence Against Women Perpetrated or Condoned by the State During Times of Armed Conflict (1997-2000)." UN Doc. E/CN.4/2001/73.

Copelon, R. 2000. “Gender Crimes as War Crimes: Integrating Crimes Against Women into International Criminal Law.” McGill Law Journal 46: 217-240.

Cossman, B. 2002. "Gender Performance, Sexual Subjects and International Law." Canadian Journal of Law \& Jurisprudence 15 (2): 281-296.

Council of Europe. 2011. "Convention on Preventing and Combating Violence Against Women and Domestic Violence.” CETS No. 210, April 12.

David M. Kennedy Center for International Studies. 1998. "Impartiality in the Election of Judges" (on file with the author).

Dickens, A. 1998. "Women Withhold Final Verdict," Terra Viva: The Conference Daily Newspaper, July 18. 
Evans, J. 1998. "Pro-Lifers Win Limits on New UN Criminal Court," The Interim (August 1998).

Farrior, S. 2003. "The Rights of Women in International Human Rights Law Textbooks: Segregation, Integration or Omission?.” Columbia Journal of Gender and Law 12 (3): 587-599.

Glasius, M. 2006. The International Criminal Court: A Global Civil Society Achievement. London: Routledge.

Halley, J. 2009. "Rape at Rome: Feminist Interventions in the Criminalization of SexRelated Violence in Positive International Criminal Law." Michigan Journal of International Law 30 (1): 1-123.

Holy See. 2011. "Permanent Mission of the Holy See to the Council of Europe, Note on the Use of the Concept of Gender, Item Reference: CM(2001)3: Draft Council of Europe Convention on Preventing and Combating Violence Against Women and Domestic Violence (CAHVIO).” Council of Europe Doc. DD(2011)199, March 21.

Holy See. 2012. "Statement by His Excellency Silvano M. Tomasi, Permanent Observer of the Holy See to the United Nations and Other International Organizations in Geneva, at the 19th Session of the Human Rights Council, Item 3, General Debate and Panel Discussion on 'Discriminatory Laws and Practices and Acts of Violence Against Individuals Based on their Sexual Orientation and Gender Identity”, undated (on file with the author).

ICC. 2012a. Prosecutor $v$. Thomas Lubanga Dyilo, ICC Doc. ICC-01/04-01/06, Judgment pursuant to Article 74 of the Statute (Trial Chamber I, March 14).

ICC. 2012b. Prosecutor v. Thomas Lubanga Dyilo, ICC Doc. ICC-01/04-01/06, Decision on Sentence pursuant to Article 76 of the Statute (Trial Chamber I, July 10).

ICC, Assembly of States Parties. 2012. "Report of the Bureau on Equitable Geographical Representation and Gender Balance in the Recruitment of Staff of the International Criminal Court.” ICC Doc. ICC-ASP/11/33, October 23.

ICC, Office of the Prosecutor. 2012a. "Gender Justice and the ICC: Progress and Reflections." Statement of the Prosecutor-elect at "10 Year Review of the ICC: Justice for All?” The International Criminal Court, February 14. http://www.icc-cpi.int/NR/ rdonlyres/FED13DAF-3916-4E94-9028-123C4D9BB0C9/0/StatementgenderSydeny 140212.pdf

ICC, Office of the Prosecutor. 2012b. "ICC Prosecutor Fatou Bensouda Appoints Brigid Inder, Executive Director of the Women's Initiatives for Gender Justice, as Special Gender Advisor.” ICC Doc. ICC-0TP-20120821-PR833, August 21).

ICC, Office of the Prosecutor. 2014. "Policy Paper on Sexual and Gender-Based Crimes," June. http://www.icc-cpi.int/iccdocs/otp/OTP-Policy-Paper-on-Sexual-and-GenderBased-Crimes-June-2014.pdf

ICC, Office of the Public Counsel for Victims. 2012. "Representing Victims Before the International Criminal Court: A Manual For Legal Representatives.” 2nd ed. http://www.icc-cpi.int/en_menus/icc/structure\%20of\%20the\%20court/victims/office \%20of\%20public\%20counsel\%20for\%20victims/Documents/26-March-2013-ENConsolidated-Version-2010-2012-OPCVManual.pdf

ICC, The Trust Fund for Victims. n.d. "The Two Roles of the TFV." http://www. trustfundforvictims.org/two-roles-tfv 
International Law Commission. 1994. "Draft Statute for an International Criminal Court, Report of the International Law Commission on the Work of its FortySixth Session.” May 2-July 22, Chapter II.B.I, UNGAOR, 49th Sess., Supp. 10, UN Doc. A/49/10, 29-140.

Kirsch, P. 1999. “The Development of the Rome Statute.” In The International Criminal Court: The Making of the Rome Statute - Issues, Negotiations, Results, edited by R. S. Lee, 451-461. The Hague: Kluwer Law.

Kress, C. 2003. "The Procedural Law of the International Criminal Court in Outline: Anatomy of a Unique Compromise.” Journal of International Criminal Justice 1: $603-617$.

LifeSite. 1998. "International Criminal Court Approved: LifeSite Report on the Approval of the International Criminal Court," July 19. https://www.lifesitenews.com/news/ international-criminal-court-approved-despite-major-victories-grave-concern

MacKinnon, C. A. 2013. “Creating International Law: Gender as Leading Edge.” Harvard Journal of Law \& Gender 36: 105-121.

McDougall, G. J. 2000. “Contemporary Forms of Slavery: Systematic Rape, Sexual Slavery and Slavery-Like Practices During Armed Conflict, Update to the Final Report Submitted by Ms. Gay J. McDougall, Special Rapporteur.” UN Doc. E/ CN.4/Sub.2/2000/21.

McFeely, T. 1998. “The Ultimate Activist Court Collapses.” Western Report, July 27: 1617.

Moshan, B. S. 1998. "Women, War, and Words: The Gender Component in the Permanent International Criminal Court's Definition of Crimes Against Humanity." Fordham International Law Journal 22: 154-184.

Oosterveld, V. 1998. Personal notes from the 11 and 13 July 1998 sessions of the Working Group on Applicable Law (on file with the author).

Oosterveld, V. 2005. "The Definition of 'Gender' in the Rome Statute of the International Criminal Court: A Step Forward or Back for International Criminal Justice?.” Harvard Human Rights Journal 18 (1): 55-84.

Pillay, N. 2008. "Protection of the Health of Women Through International Criminal Law: How Can International Criminal Law Contribute to Efforts to Improve the Health of Women?." Emory International Law Review 22: 15-27.

Preparatory Committee on the Establishment of the International Criminal Court. 1997a. "Decisions Taken by the Preparatory Committee at its Session Held From 11 to 21 February 1997." UN GAOR, 51st mtg., Annex I, UN Doc. A/AC.249/ 1997/L.5.

Preparatory Committee on the Establishment of the International Criminal Court. 1997b. "Decisions Taken by the Preparatory Committee at its Session Held from 4 to 15 August 1997." Annex II, UN Doc. A/AC.249/1997/L.8/Rev.1.

Preparatory Committee on the Establishment of the International Criminal Court. 1998. "Report of the Preparatory Committee on the Establishment of an International Criminal Court (Draft Statute and Final Act), UN Diplomatic Conference of Plenipotentiaries on the Establishment of an International Criminal Court, Rome, Italy, June 15-July 17, 1998." UN Doc. A/CONF.183/2/Add.1 (1998). 
REAL Women of Canada. 1998. Untitled Paper on draft ICC Statute article 37(7) on qualifications of the ICC's judges (on file with the author).

Rome Statute of the International Criminal Court. 1998. 37 ILM 999 (1998).

Schabas, W. 2010. The International Criminal Court: A Commentary on the Rome Statute. New York: Oxford University Press.

Sierra Leone Truth and Reconciliation Commission. 2004. "Witness to Truth: Report of the Truth and Reconciliation Commission," vol. 3b, Ch. 3. http://www.sierraleonetrc.org/ index.php/view-report-text-vol-3b/item/volume-three-b-chapter-three?category_id=9s

Singson, S. 2011. "New European Convention Defines 'Gender' as Social Construct." Catholic Family and Human Rights Institute (C-FAM), April 7.

Spees, P. 2003. "Women's Advocacy in the Creation of the International Criminal Court: Changing the Landscapes of Justice and Power." Signs 28 (4): 1233-1254.

Steains, C. 1999. “Gender Issues.” In The International Criminal Court: The Making of the Rome Statute-Issues, Negotiations, Results, edited by R. S. Lee, 357-390. The Hague: Kluwer Law.

United Nations (UN). 1996. "Report of the Fourth World Conference on Women, Beijing, 4-15 September 1995.” UN Doc. A/CONF.177/20/Rev.1.

UN. 2001. "Report of the World Conference against Racism, Racial Discrimination, Xenophobia and Related Intolerance, Durban, 31 August-8 September 2001." UN Doc. A/CONF.189/12 (2002).

UN Commission on Human Rights. 1997. "Elimination of Violence Against Women.” Res. 1997/44, ESCOR Supp. (No. 3) at 145, UN Doc. E/CN.4/1997/44.

UN Diplomatic Conference of Plenipotentiaries on the Establishment of an International Criminal Court. 1998a. "Summary Record of the 3rd Meeting." Rome, Italy, June 15-July 17, 3rd Meeting, UN Doc. A/CONF.183/C.1/SR.3 (1998).

UN Diplomatic Conference of Plenipotentiaries on the Establishment of an International Criminal Court. 1998b. "Summary Record of the 4th Meeting." Rome, Italy, June 15-July 17, 4th Meeting, UN Doc. A/CONF.183/C.1/SR.4.

UN Diplomatic Conference of Plenipotentiaries on the Establishment of an International Criminal Court. 1998c. "Summary Record of the 25th Meeting." Rome, Italy, June 15 - July 17, 25th Meeting, UN Doc. A/CONF.183/C.1/SR.25 (1998).

UN Economic and Social Council. 1997. "Coordination of the Policies and Activities of the Specialized Agencies and Other Bodies of the United Nations System: Mainstreaming the Gender Perspective into All Policies and Programmes in the United Nations System, Report of the Secretary-General." UN Doc. E/1997/66.

UN General Assembly. 1997. "Follow-up to the 4th World Conference on Women and Full Implementation of the Beijing Declaration and Platform for Action." UN Doc. A/RES/51/69.

Werle, G. 2009. Principles of International Criminal Law. 2nd ed. The Hague: TMC Asser Press.

Wilkins, R. G., W. O. Perry, and M. R. Mumford. 1998. "The United Nations Diplomatic Conference of Plenipotentiaries on the Establishment of an International Criminal Court." http://www.law2.byu.edu/wfpc/About_the_WFPC/papers/icc_report.html 